European journal of American studies

\title{
A Phosphorous History: William Carlos Williams' In the American Grain
}

\section{Antonia Rigaud}

(2) OpenEdition

Journals

Electronic version

URL: https://journals.openedition.org/ejas/11505

DOI: 10.4000/ejas. 11505

ISSN: 1991-9336

Publisher

European Association for American Studies

\section{Electronic reference}

Antonia Rigaud, "A Phosphorous History: William Carlos Williams' In the American Grain", European

journal of American studies [Online], 11-1 | 2016, document 5, Online since 02 June 2016, connection on

08 July 2021. URL: http://journals.openedition.org/ejas/11505 ; DOI: https://doi.org/10.4000/ejas. 11505

This text was automatically generated on 8 July 2021.

Creative Commons License 


\section{A Phosphorous History: William Carlos Williams' In the American Grain}

Antonia Rigaud

In the American Grain is a problematic text: written by a doctor and poet, discussing nine centuries of American history, it does not easily lend itself to categorization, seeming to float in between literature and history, offering a meditation on an object which is as elusive as the book's title. The title symbolizes the book's difficult ambition: to capture a moving object, to try and pin down what is by essence impossible to pin down-the ethos of a country that is also a continent, something with more than one national identity, which must therefore exist in the book as a geographical more than a national project. As such, the book encapsulates the question of the national versus the geographic, and challenges the separation of history and literature, bringing these categories together in a unified discourse on "America," understood both as an idea and as reality.

The quest for a definition of "the American grain" spans 21 chapters, each presenting, presumably, key moments in American history going up to 1860: these moments range from traditional historical markers such as Columbus' discoveries, the Mayflower, Cotton Mather, Washington or Lincoln to more surprising sections such as the ones on Eric the Red or Cortez and Montezuma. The former were familiar figures to the readers who had encountered them in Francis Parkman, who is quoted three times in the book (83, 91, 91), George Bancroft, or William Hickling Prescott among others, while the latter and less expected ones reflect Williams' ambition to go beyond a traditional narrative of the development of the 13 British colonies into the United States and of American exceptionalism. ${ }^{\mathrm{i}}$

Kenneth Burke, a friend and correspondent of Williams', reviewed the book for the New York Herald in 1926 and might have sealed its fate and its marginal position within the field of American studies. Burke celebrated the vitality of Williams' prose portraits but disagreed with the author's method. He wrote that the book "tends 
towards a maximum of 'interpretation' and a minimum of research.... The purpose is poetry, not history. Williams seeks bravuras rather than facts" (87). The subjective voice of "interpretation" is indeed at the heart of Williams' foray into history, where the author appears regularly to offer his own take on the chapter at hand. The historical subject hides at times behind imaginary sequences, which makes the book move towards poetry rather than history. Burke's use of the term "bravuras" to refer to Williams' series of portraits also seems appropriate, when we consider his literary experimentations or some of the portraits made of historical figures, as for instance the very striking final chapter on Lincoln where the national hero is portrayed as a woman.

Williams' reaction to Burke's review showed that he believed his project had not been understood-how the book's ambition was precisely to rethink the method of history in order to capture the country's culture:

I thought I had altered the original matter with enough historic material to have escaped the bald statement 'Subjective History,' perhaps I had miscalculated.... I didn't like the implied association between poetry and bravura. I liked well your careful desire to say something intelligent and truthful. I wish however you had sensed a sweep to the book as a whole. Maybe it isn't there but one or two friends have gotten it. (East 44)

This paper seeks to explore what Williams was expecting from his readers, what "to get it" meant for him, and how his project relied on negotiating between poetry and history in a way which actually prefigured some of the theoretical shifts in the field of history that emerged later in the century.

Indeed, Williams' historical text does not depend on a reliable authorial voice interpreting a historical event; rather, its chapters function as meditations on "the grain" of America which are distributed in an echo chamber of quotations and voices. If the table of contents makes the reader aware of the particular sense of history that the work seeks to bring forward and its relatively chronological order, it is the central chapter entitled "Père Sebastian Rasles" that gives the clearest expression of William Carlos Williams' project: to debunk official history, to cleanse the stench of a genteel history which clings to the present. Williams' historical project is thus organized as a quest for a "thing," for an American reality that must be purged and disentangled from the traditional story of the country's history. Williams' commitment to history is vital for his personal sake as well as for the sake of excavating the "truth" in history. This chapter functions as the book's methodological center, but it must be noted there are many other chapters where the author expresses his ambition as a historian, turning a reflection on the method of the book into a reflection on the way of "doing" or "writing" history, mingling the object and the method together, and trying to counter the book's opposition to a history of lies: "history, history, that lie!" (192). History is indeed as much a subject of the book as the lives of the men who have made it. It is a recurrent object of discussion, which the book tries to capture, but which remains elusive: a "thing," a "lie," a "tyranny" (189), terms which suggest Williams' particular take on history not as a set method, but, as we shall see throughout this paper, as a process to be continually reassessed.

In In the American Grain, both the objective and the personal relation of the researcher to the historic object are subjected to questioning. The exchange between Burke and Williams frames the way this paper looks at a book that oscillates between claiming its "unprofessional" stance and trying to capture something which traditional history cannot capture: the fleeting sense of a place's culture. A first part will be 
devoted to the way Williams' book operates in its historical context and in particular the modernist moment, which paid so much attention to the issue of a "usable past" or tradition. The second section looks at In the American Grain as variations on recurring motifs in American history: beginnings and discovery-two motifs which hide the violence of the country's history while allowing Williams to anchor his modernist experimentations in the local and reflect on its importance in the construction of a national ethos. The third part focuses on Williams' historical project as a "homemade" history, deeply grounded, as Hugh Kenner said of American modernism, in the specific conditions of life in America. This project, which demands an exploration of the multiple voices of American history, was well-served, by Williams' attention to techniques of collage and montage.

\section{In the American Grain: An Archive of Early Twentieth Century American Thought}

Written in 1925 in both the United States and Europe, In the American Grain is Williams' attempt at uncovering the true ethos of his country, which he presents as buried under layers of false discourses. The book exemplifies the rise of voices that came to oppose the national narrative, but also reads as a reaction to Williams' fellow avant-garde writers.

\section{1. Williams as Cultural Critic and Dissenter. In the American Grain in Context}

In the American Grain belongs to a recognizable genre of early twentieth-century America, the critique of the American experience that constituted a large part of the critical and fictional work of the 1920s-from Van Wyck Brooks' exploration of American letters and culture to John Dos Passos, whose 1925 Manhattan Transfer echoes in many ways Williams' reflection on the state of his country, or to Hart Crane's attempt at a national epic in The Bridge. The book belongs indeed to an era marked by the need to constitute a counter-narrative to the American canon. In Writers in Retrospect: The Rise of American Literary History, 1875-1910, Claudia Stokes has shown how the rise of American literary history in the late nineteenth century led the way to F. $\mathrm{O}$. Matthiessen's 1941 definition of the American Renaissance, but one should also keep in mind that the constitution of a literary canon was accompanied by the search for a counter-narrative. Williams' perspective on literary figures in In the American Grain is a good example: tellingly, he mentions neither Emerson nor Whitman, whom one would expect to be guiding lights for his project, but focuses on Poe, who has always had an eccentric position in the American canon (in fact, Poe is the only real "writer" in Williams' book). He reflects on what D. H. Lawrence called in his 1923 Studies in Classic American Literature the country's "dark, aboriginal continent" and the way in which the Europeans who "discovered" it failed to come to terms with the rupture it represented with the old world. The text spells out the tradition of violence that Lawrence had asked to be rediscovered:

Americans must take up life where the Red Indian, the Aztec, the Maya, the Incas left it off. They must pick up the life-thread where the mysterious Red race let it fall. They must catch the pulse of the life which Cortes and Columbus murdered. 
There lies the real continuity not between Europe and the new states, but between

the murdered Red America and the seething White America. (Studies 384)

Indeed, if Williams' choice of historical figures sometimes intersects with Lawrence's (Benjamin Franklin and Edgar Allan Poe), his historical narrative makes room for "the Red Indian, the Aztec, the Maya, the Incas," while Lawrence's work did not. Williams takes Lawrence up on his call to rediscover the continent's history of raw violence and positions himself as an authoritative cultural critic whose project is to run against a monumental and European-like history. Inside traditional figures he finds diverse and dissonant voices. In the rather small space afforded by his essays, he blends in together many different perspectives on this history, but the text always seeks to remain true to the violent energy and desire that accompany the various moments of the New World's "discovery." The discoverers, as described in "The Destruction of Tenochtitlan," "moved out across the seas stirred by instincts, ancient beyond as the depths they were crossing" (In the American Grain 27). The motif of an instinctive violence, of the primitive forces that drove Europeans across the Atlantic Ocean speaks to a certain confinement and obsolescence of the European. This energy turns into an almost psychoanalytical narrative of desire that is depicted in the "Sir Walter Raleigh" chapter for example: "of Raleigh, believed by majesty, plunging his lust into the body of a new world-and the deaths, misfortunes, counter coups, which swelled back to certify that ardor with defeat" (59). The text thus signals the contemporary focus on the primitive and reappraisals of native nations, something which American anthropology, in the wake of Franz Boas' work, was putting at the forefront of scientific research. ${ }^{\text {ii }}$

This emphasis on violence and murder situates Williams very close to contemporary anthropologists, as Susan Hegeman suggests in Patterns for America: Modernism and the Concept of Culture. Williams' figures and events were chosen, for the most part, from the stock of American legends: John Paul Jones, the naval captain of the Bonhomme Richard; Daniel Boone, the great pioneer; George Washington, father of the country; Benjamin Franklin's "Poor Richard;" but they are presented from a perspective that is anything but heroic. In addition, Williams evidently believes that the story of the "New World" requires going beyond the circumference of the United States proper, and dealing with such personalities as Cortez and Samuel Champlain; at the same time, Williams does not want to define the American grain strictly in terms of biography: slavery, or women, are also his concerns and cannot be summed up by one figure. In other words, to borrow the categories defined by Hayden White in Metahistory (11-13), Williams' historical ambition was to "chronicle" American history rather than focus on "story." The historical text as chronicle allows Williams to look at recurring trends in the ethos of the "American," a category that refers throughout the book to primitive violence.

In Beloved Community: The Cultural Criticism of Randolph Bourne, Van Wyck Brooks, Waldo Frank and Lewis Mumford, Casey Nelson Blake shows the role played by the Young Americans in bringing together notions of culture, self and society to imagine a new democratic culture, and underlines the context in which Williams was defining his vision of blended history and poetry as a way of shaping a new democratic ideal. Williams' clear didactic stance positions him within the context of an era that lay the ground for the rise of cultural criticism in the 1980s, bringing together literature and history. If In the American Grain has mostly been read as a literary text, it is important to see how it blurs the frontiers between these two realms in a way which evokes more recent reflections on the uses of literature to understand history. ${ }^{\text {iii }}$ 
It appears from these first elements that the book, even though it was only first published at a thousand copies and not publicized by its publisher, ${ }^{\text {iv }}$ was actually part of a trend in American intellectual life, one that sought to oppose the idea of a monumental national narrative. As Williams was well aware, deflationary contemporary reflections on the American ethos, from George Santayana's 1911 "The Genteel Tradition in American Philosophy," which influenced Van Wyck Brooks' 1915 America's Coming-of-Age, to Sherwood Anderson's tales, had become a ritual not only among the avant-garde, but also among academic critics and media figures in the popular press. Williams' severe indictment of Puritanism in the book indeed echoes Mencken's many scathing anti-Puritan articles. Even though Williams had very little patience with the "sage of Baltimore," babbitry and a passion for the American language. The two men both responded to the Eurocentric gaze of their American contemporaries with irony: both despaired of the lowbrow American mainstream in the twenties, although Mencken took this comically, and Williams, tragically.

These voices were influenced by yet other voices in the post-World War I era that tried to bring "counter-narratives" to the official histories of their countries, such as Lytton Strachey's demystification of the Victorian era in England, or the Surrealist attack on the bourgeois culture in France. Williams' endeavor to define the American mind was resonant with a moment that combined the demystification of patriotic narratives with anxieties about the seeming drift of "Western" culture. His selection of characters on which to build his history of America is therefore emblematic of his desire to represent a genuine gallery of portraits rather than one that had been sacralized by tradition; like many of his contemporaries, he wanted to write a history of America that would be stripped of bias, of what he called "this American religion which we have inherited so largely from the Puritans" (In the American Grain 127), thus following in the path opened by Brooks' 1908 The Wine of the Puritans.

In his review of In the American Grain, D. H. Lawrence wrote: "History in this book would be a sensuous record of the Americanization of the white men in America, as contrasted with ordinary history, which is a complacent record of the civilization and Europizing (if you can allow the word) of the American continent" ("Review" 90). The collection reads indeed as a strong statement against what D. H. Lawrence calls "ordinary history," which refers to the dominating historical vision of the continent being civilized by Europeans, opposing this discourse by using various strategies to undermine, or, to speak in modern terms, to deconstruct it. vi Van Wyck Brooks had presented the American experience as chaotic and disordered, something which Williams also tries to capture in the book. Brooks wrote:

America is like a vast Sargasso Sea-a prodigious welter of unconscious life, swept by ground-swells of half-conscious emotion. All manners of living things are drifting in it, phosphorescent, gaily colored, gathered into knots and clotted masses, gelatinous, unformed, flimsy, tangled, rising and falling, floating and merging, here an immense distended belly, there a tiny rudimentary brain (the gross devouring the fine) - everywhere an unchecked, uncharted, unorganized vitality like that of the first chaos. (America's Coming-of-Age 164)

The direct echo between Brooks' "phosphorescent" America and Williams' attempt, as he explains in his foreword "to draw from every source one thing, the strange phosphorus of the life" brings to the fore the book's deep relationship with contemporary intellectual discourses along with the desire to capture what is 
essentially evanescent. This "grain" calls for a critical voice, one that will not be afraid to look at violence and desire and will go against the "genteel" America that Williams already indicted in his 1923 collection of poems Spring and All, especially in "The Pure Products of America Go Crazy":

as if the earth under our feet
were
an excrement of some sky
and we degraded prisoners
destined
to hunger until we eat filth
while the imagination strains
after deer
going by fields of goldenrod in
the stifling heat of September
somehow (I 131)

The poet's ambition is to give expression to the "pure products of America," to bear witness, to "give character," to "adjust" and to show the poetry of the land which is not to be seen as the "excrement from some sky" but as the American experience in all its diversity. This will be an essential part of the gallery of portraits of In the American Grain.

\subsection{Defining a "Usable Past": Williams' Modernist Historical Project}

In a highly influential article published in The Dial in 1918, Van Wyck Brooks called for the creation of a "usable past":

The present is a void, and the American writer floats in that void because the past that survives in the common mind of the present is a past without living value. But is this the only possible past? If we need another past so badly, is it inconceivable that we might discover one, that we might even invent one?

Discover, invent a usable past we certainly can, and that is what a vital criticism always does ("On Creating" 339).

The way Brooks mingles history and invention influenced Williams powerfully and opened the way for his experiment in poetic history. In the preface to In the American Grain, Williams explains his historical project by emphasizing his role as a creator: "In these studies I have sought to re-name the things seen, now lost in chaos of borrowed titles, many of them inappropriate, under which the true character lies hid... I have recognized new contours suggested by old words so that new names were constituted" ("Foreword"). The choice of the verb "re-name" and the necessity to constitute "new contours" and "new names" emphasize his focus on redefining the past in order to make it meaningful in the present and evokes Van Wyck Brooks' influence. Williams similarly seeks to debunk a tradition that was defined by the Puritans, "a race incapable of flower" (In the American Grain 66) and calls for a critical perspective on America's intellectual tradition. In order to replace it within a living tradition, Williams devotes a chapter to the French Jesuit missionary, Rasles, a lesser known figure: "Contrary to the English, Rasles recognized the New World. It stands out in all he says. It is a living flame compared to their dead ash" (120). Williams' project of a dissenting and "liberated" history of the country is itself part of a long tradition of dissent, and one thinks here of another towering intellectual figure which looms over the essays, that of Emerson and his call to stop building the "sepulchres of the fathers" (Emerson 7). However, the fact that Williams chose not to refer to Emerson shows it was dissent 
rather than continuation that he was interested in along with a new language to name the American experience.

In the American Grain was composed during a sabbatical from his medical practice in 1923-4, during which Williams researched materials at the public library in New York and then made the crossing to Europe in the spring, where he met many of the age's artistic avant-garde:

Picasso (turning to look back, with a smile), Braque (brown cotton), Gertrude Stein (opening the doors of a cabinet of MSS), Tzara (grinning), André Germain (blocking the door), Van der Pyl (speaking of St. Cloud), Bob Chandler (prodding Marcel), Marcel (shouting), Salmon (in a corner) and my good friends Philip and Madam Soupault; the Prince of Dahomi, Clive Bell (dressed), Nancy, Sylvia, Clotilde, Sally, Kitty, Mina and her two lovely daughters; James and Norah Joyce (in a taxi at the Place de l'Etoile), McAlmon, Antheil, Bryher, H. D. and dear Ezra who took me to talk with Léger; and finally Adrienne Monnier-these were my six weeks in Paris. (In the American Grain, "Père Sébastien Rasles" 105)

The list of names shows how the trip to Europe was a probe into the avant-garde of the time, something that the paragraph captures well with these slanted, partial and yet very telling presentations of this flurry of names, or characters in a play as the use of quasi stage directions seems to suggest. The passage opens the path for In the American Grain's gallery of portraits, cubist in its way of focusing on some traits, actions, moments, rather than on a grandiose classical picture. It is however interesting that these encounters with European or Europeanized American avant-gardes led Williams to an even greater concern with his country's culture and specificities.

Pound had challenged Williams to travel to Europe: "I think you are afraid to take a sabbatical in Europe, for fear of destroying some illusions which you think necessary to your illusions" (Voyage xii). Williams seized this as an opportunity to take a backward glance at his home country, to try to capture the "grain" of the American experience. He knew very well that many of his contemporaries and friends, from his friends H. D. and Pound to T. S. Eliot, considered Europe as the locus of modernity and creative freedom. But expatriation to Europe meant a detachment from the American experience, the local, which Williams considered the source of art and which explains his skepticism towards the avant-garde's tendency to look to Europe as a ground for artistic explorations and experimentations. Already in 1920, as John Beckhas pointed out, Williams was impressed by an article John Dewey wrote for The Dial that argued that "the locality is the only universal" (Dewey 697), using that phrase in a manifesto in the second issue of Contact, a little magazine he edited.

The journey to Europe became, in In the American Grain, an intellectual dialogue between Europe and America, as enacted in the "Père Sébastien Rasles" chapter and continued in 1928 in the autobiographical travelogue A Voyage to Pagany. Europe offered Williams the right distance to look at America from a "foreign perspective," a literal experimentation with his Puerto-Rican and European heritage. Interestingly, Williams equates the object of the book, which is to rediscover the meaning of the word "American," with a literary endeavor: "Our resistance to the wilderness has been too strong. It has turned us anti-American, anti-literature. As a violent 'puritanism' it breathes still" (In the American Grain 116). The equation between "American" and "literature" enhances Williams' turn to imagination and literature to appraise his country's history. The question of defining the "American grain" seriously takes the "imagination" as a historical and collective force. In a way, Williams was probing the 
construction of what Benedict Anderson has called "imagined communities," a community or nation that finds its unity in a collective act of identity with what the members imagine the community to be.

\section{Historical Variations}

In the American Grain follows a chronological order but does not ground itself in the idea of progress; rather, it reads as a series of variations on the same motifsclosedness and openness, the local; each chapter presents another aspect of these themes, another stylistic experiment. The book does not so much present the evolution of the continent's history as suggests that its history is made of repetitions with variations, never truly offering change or evolution. ${ }^{\text {vii }}$

\subsection{Beginnings: The "Tradition of the New"}

In the American Grain looks at the "beginners" that have made American history, from the Spanish explorers to Poe, and questions the notion of an American innocence. Indeed, a country of beginners is one where the weight and violence of the past do not exist and can be forgotten under the celebration of the present. Williams' project of writing history in a country that fantasizes itself as innocent is precisely to show how the narrative of innocence produces an official history that purges the past of its violence and terror; in order to keep the illusion of innocence, the historical narrative exercises another violence, that of a collective mental repression. Williams opposes the violence of this supposed original innocence to the violence of the imagination: "However hopeless it may seem, we have no other choice: we must go back to the beginning; it must all be done over; everything that is must be destroyed" (215). In that sense, the writer shares some of the frontiersman's conditions, such as Daniel Boone: "The fields for adventure lay within his reach. The mountains were to be crossed and a new and unexplored country, invested with every beauty, every danger, every incident that could amuse the imagination or quicken action, lay before him, the indefinite world of the future" (132).

The metaphor of the blank page, so often applied to America, is brought forward as a gesture that rids the continent of its Native American inhabitants in one sweep: the discoverer will exercise his imagination and write the future of the country. Yet Williams, as so often in these essays, immediately swings to another pole and does recognize the existence of Natives: Boone's triumph is explained by his embrace of the "savage" lifestyle. The motif of discovery is presented as seminally American, the modality under which the American character is formed. It is around this motif that Williams brings together Eric the Red, Columbus, Cortez, Samuel de Champlain and the Puritans, creating a narrative of "American history" that encompasses the whole enterprise of dominating the continent.

Williams' own intellectual discovery is how much the independent nation existed first as an idea rather than as an experience, the idea of discovery being stronger than the experience of discovery. This was not of course Williams' invention. John Winthrop's famous sermon aboard the Arabella, "we shall be as a city upon a hill" has been the underlying, utopian motif of American expansion. The image suggests that intention motivated the country's history, that the country was an idea before it was a 
reality, that it was exemplary even before its creators had set foot on the continent. But what has shaped American history is at the very heart of America's "original sin" as well. Williams in In the American Grain is so strongly against the national narrative that grounds American history in the Puritan experiment that, as Charles Olson wrote in his copy of the book, he "witchhunts the Puritans" (Von Halberg 228).For him, this was a history based on "an atavism that thwarts and destroys" (In the American Grain 68). The position was not that uncommon in the 1920s, but Williams invested it with a particular violence. The author's historical project is indeed based on the necessity to refresh history, to find "contact" with facts and times in order to give new life to the historical process of creating a country of shared values, united by a common "grain." It is therefore not so much a question of getting close to the "truth" as to the "grain," viii or to create an imagined community through the text, one that would share the same taste for a reappraisal of set narratives, one that would be as close as possible to the local, the soil of the American experience. Historical facts thus fade behind poetic facts, which become the core of this history of America.

Each chapter of In the American Grain is concerned with the success or failure of new endeavors to re-enact a beginning. This reads symbolically like the modernist attempt at "making it new!" to follow the slogan of Williams' friend and nemesis, Ezra Pound. However, for Williams, writing a book of history that is about beginnings encapsulates very well his particular position within the modernist canon. Both a beginner, a modernist interested in creating things from scratch, and an amateur historian, interested in finding the deep-rooted explanations of the present with which he could explain his world, Williams positions himself throughout the chapters as both a historical researcher and a writer, redefining history from a non-professional perspective.

"Good lord, these historians!" (In the American Grain 69). Historians are considered as fossilizers, turning discovery into history, ossifying it: "But history follows governments and never men. It portrays us in generic patterns, like effigies or the carvings on sarcophagi, which say nothing save, of such and such a man, that he is dead. That's history. It is concerned only with the one thing: to say everything is dead" (188). History as it is practiced in In the American Grain opposes the grand historical narrative of Williams' modernist American counterparts who had chosen Europe. In contrast to T. S. Eliot's traditionalism or to "traditionalists of plagiarism" (Spring and All, I 94), Williams was not looking for a history that froze literature or culture in an exemplification of timeless values, but rather sought to liberate them from the monumentality of official stories. Unlike Eliot's Wasteland, for example, In the American Grain does not seek to secure its historical foundations through the use of references but rather loosens its references to the point where the reader is never quite certain of the historical accuracy of what he reads.

Williams was also firmly opposed to Pound's nostalgia for an authoritarian order: Pound's Cantos included a version of American history, extolling America's founding fathers, equating Jeffersonian agrarian values to fascism, and his personae do not consider the possibility of oppositional views, while Williams' insistence on his subjective point of view is constructed around the very notion of a possible refutation. Williams' mingling of history and literature echoes what Pound was doing in his Cantos, a collage of quotations and references, but the quotations function very differently: Pound's historical ambition was didactic, while Williams' was hermeneutic. It must be 
noted however that Williams' historical method owes to Pound's concept of the "luminous detail," which is what Williams explores throughout the book, looking at all the facets of the details illuminating the lives of the characters.

While Williams' treatment of history evokes Eliot's and Pound's, his method was much less authoritative as it intended to debunk canonical history rather than spell out a canon. Williams was therefore much closer in his ambition to what the Young Americans were doing.

\subsection{Discovering the Local}

Williams famously wrote in Paterson "no ideas but in things" (5), a motto which informs his whole career and helps to understand the moral test that some figures pass, and others fail in the book. The latter are marked by a misplaced idealism, fed not from the spring of experience, but from the mental predispositions of the discoverers. When ideas or intentions predominate, a screen distorts the experience of things. Williams suggests for example that the idea of the "promised land," over these nine centuries, is what explains the violence of the American experience because of the absence of connection between the idea and "things"-or the concrete experience of a continent that is all wilderness at first. This notion resonates with what Stein would say much later in Wars I have Seen: "Anybody is as their land and air is" (Douglas 202), where one can hear the Williamsian concern with knowing history through the local.

Marianne Moore referred to Williams as "our Audubon of locality and American behavior" (Whitaker 8) and the phrase, if ironic, shows very well how his project was to write as closely as possible to the ground, to capture iconic instances of the native, something he explains clearly in "The Discovery of Kentucky": "For the problem of the New World was, as every new corner soon found out, an awkward one, on all sides the same: how to replace from the wild land that which, at home, they had scarcely known the old World meant to them; through difficulty and even brutal hardship to find a ground to take the place of England" (In the American Grain 136). Among In the American Grain's figures, it is no accident that it falls to Poe, the only writer, to symbolize a "genius intimately shaped by his locality and time" (216); his language "is a remarkable history of the locality he springs from" (223). In the American Grain is a story of how individual figures have encountered the American continent and how most of them have failed because of the desire "to find a ground to take the place of England." The chapters thus call for a reappraisal of history from a geographical perspective. This explains the clear-cut opposition between characters who have "a genius of place" (216) and characters who fail to come in contact with the local, like the Puritans, described as "incapable of flower" (66) because they never rooted themselves in the land but only tried to copy their former lives in Europe.

Williams calls for a type of history that would look to the ground and be able to bring together poetic questions and the local, which, to Williams, referred to the way communities built themselves in a particular space. The "Descent" chapter, devoted to Samuel Houston, makes the point very clearly: "He wants to have the feet of his understanding on the ground, his ground, the ground, the only ground that he knows, that which is under his feet. I speak of aesthetic satisfaction" (213). Williams here promotes what Emerson called "an original relationship to the universe" (Emerson 7), a form of innocence defined by a direct and unmediated relationship to the local. This 
notion, which often recurs in In the American Grain without ever being fully argued, will influence a whole group of later writers, most notably Charles Olson, whose own extended contribution to literary history, Call me Ishmael, unites literature and history, the study of the American whaling industry and Melville. In Williams, it is the sense of the local and of the particulars of experience that orient the text towards mundane and quotidian aspects: "In history, to preserve things of 'little importance' may be more valuable-as it is more difficult and more the business of a writer-than to champion a winner" (In the American Grain 76). Being as close as possible to the ground is part of Williams' poetic project, one that derives from Emerson's attention to the "familiar, the low" (Emerson 68-69). But one can also hear Dewey's later call, in 1920:

We have been too anxious to get away from home. Naturally that took us to Europe even though we fancied we were going around America. When we explore our neighborhood, its forces and not just its characters and colour, we shall find what we sought. The beginning of the exploring spirit is in the awakening of criticism and of sympathy. (688)

The "criticism and sympathy" that Dewey calls for is at the heart of In the American Grain, which claims "It is imperative that we sink" (214), encouraging the readers to look at the specificities of American localism, to plunge into the ground to discover the "grain" of American culture. It appears from this that discovery and the beginnings that constitute the narrative thread of the book need to be experienced rather than imagined.

The encounter with the local raises the question of the community that is built on this ground. The book opposes characters who manage a true encounter with the local, such as Sébastien Rasles, Daniel Boone, Aaron Burr, Sam Houston, or Edgar Allan Poe, and characters and communities which are incapable of such an encounter, such as the Puritans. The individuals who do manage this encounter with the local are defined by their incapacity to be part of a community. The Puritans do form a community, but one which cannot function properly precisely because of its absence of contact with the specificities of the American experience. Daniel Boone's explorations and contact with the land are presented as the natural conclusion of his refusal "to mingle in the wild wranglings and disputings of the society around him" (131). The American experience is thus marked by an inherent tension between contact with the local and the sense of belonging to a culture.

If there is a utopian aspect to the book, it is the implicit suggestion that the country can create true communities if they are really anchored in the local. Indeed, Williams' history of America is a history of individual actions seen from the vantage point of their symbolic significance for the country's collective imagination and for the country as a community in the making. The text creates a dialogue between the role of the social structure and the individual, but the concentration is ultimately on characters, with the implication that their choices are the most important historical force.

The chapter on "The Advent of the Slaves," however, is an interesting case in point as it does not present a historical figure but rather lays out a series of anecdotes relating to characters from Dr. Williams' medical practice, "the colored men and women whom I know intimately" (208): "There was Georgie Anderson," "And there was Dudu," "And there are many others" (211). The historical text here, three chapters before the end of the book, emerges briefly as a silent accompaniment to the previous chapters. Indeed, when Williams writes, "Poised against the Mayflower is the slave ship" 
(208), he is calling for a re-reading of the previous chapters from a new perspective, one that would take into account a shadow history. Williams here prefigures Ralph Ellison's 1970 seminal essay "What America Would Be Like Without Blacks," which explores the essential role of African-American culture on/in the "American grain." Williams' racist bias cannot be denied ("All the rest is to keep from having to say anything more-like a nigger: it is their beauty. When they try to make their race an issue-it is nothing"; 211), he also exoticizes African-Americans as Others, a few pages before, when he refers to the inauthentic black singers of opera as opposed to the authentic black entertainer, Bert Williams, thus denying African-Americans the full spectrum of artistic expression. It should be noted, however, that he also celebrates the impact of African-Americans on American culture with the language of "M," one "of the colored men and women whom [he has] known intimately": "I wish I might write a book of his improvisations in slang" (211). Indeed, despite his prejudice, Williams' perspective is that of a liberal in the early twentieth century, one who hopes to make his readers see "we" as "the others":

We are, too, the others. Think of them! The main islands were thickly populated with a peaceful folk when Christ-over found them. But the orgy of blood which followed, no man had written. We are the slaughterers. It is the tortured soul of our world. Indians have no souls; that was it. That was what they said. But they knew they lied-the blood-smell proof. (41).

In the American Grain does not rise much above the prejudice of its time, but it does point to the author's dissatisfaction with American society. If the call for the rediscovery of the local extends to an ethos of respect for experience, Williams' idea of the creation of a genuine community does take on a pluralistic tone. This tension explains Williams' plunge into history: poetry is presented as a way of bringing together the community and its ground. His perspective on the notion of the local is therefore very different from contemporary approaches of the local equating it with identity. The focus on the local, in Williams, connects history to places and people, and insists that the way in which the land was inhabited and dealt with informed everyday experiences. Williams wrestled with what the local meant as he did not consider it as a pre-existing concept but as a notion bringing together the ideas of place, experience and language.

\section{Williams' “Homemade" History}

Going back to Kenneth Burke's indictment of Williams' vein of poetic history, it is important to see whether the "usable past" can become a usable history, to explore whether In the American Grain may be seen as a text contributing to reflections on history. Much in the vein of Kenner's "homemade world," Williams' history is meant to go beyond the screen of official history-the historical project of killing the past, as he sees it-to find patterns and modes of experience that are deeply ingrained in the American experiment. Williams' professed "homemade" history is grounded in both the unconscious strands of the social imagination and their repression. Between the two there exists a network of symbols and facts, which leads to what he calls the "imaginative understanding of life" (Imaginations I 112) and which the poet-historian's task is to excavate. 


\subsection{Williams' “Representative Men”}

Williams' choice of 21 portraits, with most of the chapters focusing on one key historical figure, follows a traditional form of historical text, calling to mind Carlyle's On Heroes, Hero-Worship and the Heroic in History (1841) or, closer to him, Emerson's Representative Men (1850). In his preface, Williams refers to these portraits as "configurations," which is very different from Carlyle and Emerson who used a vocabulary of heroism, or the monumental. The word configuration spells out a vocabulary of construction and assemblage. In the nineteenth-century tradition, the figures have an essential core, which they share: "So with Franklin, the tone is frightened and horribly smug-at his worst; it flames a little in De Soto; it is necessary to Boone to lose himself in the wilds; there are no women-Houston's bride is frightened off; the New Englanders are the clever bone-men. Nowhere the open, free assertion save in the Indian: this is the quality" (155). Williams implies that this core is, in fact, an artifice, part projection of the audience or community, part projection by the figure itself. The text departs from traditional hagiographic history as it takes figures that are representative but strips them of their status in order to show the high cost of becoming representative: it requires the sacrifice of creative energies, which turns these figures into "a kind of swan song, each one" (143).

The key to this theme is found in the chapter devoted to Daniel Boone, "The Discovery of Kentucky." The chapter opens in a violent indictment of the "niggardliness of the damming puritanical tradition," "the miscolored legend" that buried the hero who was "left for rotten" (131). Williams' historical project, from this angle, is, as he often repeats, to rid the heroes of the symbolism that history has attached to them and thus to free them, or at least us, to find new symbols (or no symbols at all), in order not to "imprison" men in a stale definition: "If we cannot make a man live again when he is gone, it is boorish to imprison him dead within some narrow definition, when, were he in his shoes before us, we could not do it. It's lies, such history, and dangerous" (190). Imagination is therefore a protection against "lies" and serves to free historical figures from a constricting, heroic, identity, to get as close as possible to their past reality by seeing them through a personal relation, or in other words, a relation that is never totalizing.

Williams draws from the tradition of histories as chronicles of the deeds of great men, of "representative men," as Emerson put it in his eponymous essays, but with a very different aim, which was to give "new names" to these figures. This project actually echoes Emerson's notion that "there is properly no history; only biography" (Emerson 240). But Williams' biographies always hesitate between representing these figures as we have seen them, retrospectively, in official histories, and raising the question of what they really were as contingent persons.

In the American Grain is indeed concerned with "incarnating" the lives of representative figures, representing them as bodies much more than as ideas or virtues. This underscores Williams' project of infusing history with life and reality, which implies, paradoxically, the destruction of the historic image. Williams seems to suggest that traditional history preconceives the hero by placing him (rarely her) in a pre-determined story, whereas history as a poetic truth understands the human through contingency and the chances of experience. Williams' destruction of the "sepulchres of the fathers" brings imagination at the core of the historical text. 
Claiming the necessity to strip heroic figures of their titles, Williams suggests the necessity for American history to be "democratic," to take historical figures as individuals, not as heroes. D. H. Lawrence explained Williams' project by suggesting the importance of poetry to bring out the energy of history:

In this record of truly American heroes, then, the author is seeking out not the ideal achievement of great men of the New World, but the men themselves in all the dynamic explosiveness of their energy. This peculiar dynamic energy, this strange yearning and passion and uncanny explosive quality in men derived from Europe is American, the American element. Seek out this American element-of Americans!is the poet's charge. ("Review" 90).

Lawrence explains very well how the poet's intervention in the historical realm can bring a new dimension to history by infusing it with the "explosive energy" that drove these individual lives. Williams also suggests this when he compares Champlain with "a sort of radio distributor sending out sparks to us all" (In the American Grain 70): the radio sending out sparks operates very much like the text which seeks to awaken its readers with sparks of surprise. The image of the radio distributor encapsulates Williams' historic-poetic modernist project, which is to revise the historical method by bringing in the poet's attention to language.

\subsection{The Voices of History}

The authorial voice of In the American Grain is simply one frequency within a polyphonic construct. "[B] report of the witchcraft trials verbatim," "a story of a battle at sea," "the odd note," "letter by Franklin to prospective emigrants," ("Foreword," n.p.) are some of the sources listed in the foreword.The authorial voice flows into and out of other voices, as for example in the Washington chapter where it blends together anecdotes ("And then there was the obscene anecdote he told that night in the boat crossing the Delaware"; 142), general truths, later debunked by the narrator's comment, followed by a historical source (Jefferson's letter) and a final truth: “America has a special destiny for such men, I suppose, great wench lovers-there is the letter from Jefferson attesting it in the case of Washington, if that were needed-terrible leaders they might make if one could release them" (143). The very notion of truth is not separated from imagination and the truth sought by the text is based on sensation rather than knowledge.

The poetic task of the text is to "release them [the voices 50 ," giving them existence through the text's many strata: from narrative to account to direct discourse. The reader cannot always disentangle facts from literary creation, thus adding another layer of uncertainty to the text. Williams uses the method of collage and montage to bring together separate chapters but also separate voices and vignettes within one chapter. The various chapters are not part of a master narrative but exemplify a method that seeks to bring new life to history in order to leave it "undecided."

Williams' historical project is thus to unfix history by bringing poetry into the historical frame. History is questioned from the perspective of the voices that it stifles or allows to be heard. The author's position as an "unprofessional" historian allows him to look at historical texts from a distance and to question their validity. Indeed, the different narrative perspectives form a panorama and show that history cannot be monologic for Williams. In this respect, "Voyage of the Mayflower" exemplifies well his method of historical polyphony: the chapter quotes from various historical sources, 
refers to them in passing, comments on them, before ultimately closing on a final indictment of the Puritan mind.

The question of sources is at the heart of a text that never fully discloses the origins of the facts it uses. There are different textual layers in many chapters, ranging from historical documents, referring to their authoritative power, such as the letter from Jefferson about Washington (143), commentaries on the historical sources ("notes for a commentary on Franklin"; 153-157), or uncertain texts where the reader is not quite sure where the authorial voice lies (invented text? transcribed text?) or finally texts promoting historical facts through works of the imagination as in the Sir Walter Raleigh chapter where the authorial voice pastiches Milton.

The chapter "The May-Pole at Merry Mount" is a scholarly reflection on historical narratives: presenting the texts and dismissing them as not being true enough to the character of Morton. The text tends to dismiss and undermine American history, trying to bring to the fore a forgotten history: "Poised against the Mayflower is the slave ship" (IAG 208). The parallel and the silent history of that second ship which, Williams tells us, has no history: "There is little use, after all-save in a title-of speaking of the advent of the slaves; these were just men of a certain mettle who came to America in ships, like the rest. The minor differences of condition were of no importance-the mere condition of their coming is of no importance-" (208). The narrative voice is again, as in many chapters, omniscient, yet slanted, adopting, here, the common thought-a voice that does not offer facts or analyses but rather simply conveys accepted and deadly truths. The repetition of the phrase "of no importance" underlines the absurdity of the claim and turns the supposedly distantiated voice into one that carries with it the weight of centuries of prejudice as well as the unreliability of testimony.

The voice of Native Americans is also represented as a liberating force and a way of touching the ground. Boone is indeed celebrated for his "Indianlike" attitude, which allows him to get closer to the American reality: "Like an Indian," "with the sense of an Indian," "like a savage," "as an Indian to the wild," "to be himself in the new world, Indianlike" (137). The focus on Native Americans gives Williams the poetic freedom to speak what he calls "the wild language" (46) in an evocation of Whitman's "barbaric yawp," which testifies to his poetic and political ambition. Williams seeks in history the validation of the contemporary cultural relativism of Boas: "to create, to hybridize, to crosspollenize,-not to sterilize, to draw back, to fear, to dry up, to rot. It is the sun. In Rasles one feels THE INDIAN emerging from within the pod of his isolation from eastern understanding, he is released AN INDIAN" (121).

In the American Grain is built upon the idea that history is owned neither by historians nor institutions. But more than an act of anti-establishment rebellion, Williams' construction principle contains an internal contradiction between, on the one hand, assembling a history that does justice to the beginning and, on the other, the destructive process of collage and polyphony. The text puts forward the need to constantly reappraise history, to constantly verify points of view, to get as close as possible to the truth and sometimes, in the name of that quest, to shatter the narrative or the commonly accepted facts. In doing this also, the text brings forward a relative definition of truth which is contingent on point of view.

Along with the polyphony of the text, meaning is also multiplied by the sometimes jagged juxtaposition of chapters. In the American Grain operates as an open text, where 
meaning is very often left to the reader's interpretation. The George Washington chapter ends on such an open note: "He is the typical sacrifice to the mob-in a great many ways thoroughly disappointing" (143). The chapter's final word, "disappointing," remains unclear as the point of view adopted could be that of many different perceptions: the author's, the character's, the mob's. The chapter thus ends abruptly, on a subjective analysis whose subject remains uncertain and the object of conversation -something which Williams had already explored in his poems.

\subsection{Capturing "the Phosphorus of the Life"}

The book shatters our vision of these "representative men," making them hard to grasp, and attests to how the techniques of contemporary visual artists such as Marcel Duchamp, or the technique of film and montage deeply influenced Williams. He had been playing with the cubist method in his work since 1917-in Kora in Hell, he tells an anecdote that represents his own aesthetic intuition: "according to Duchamp... a stained-glass window that had fallen out and lay more or less together on the ground was of far greater interest than the thing conventionally composedin situ" (Imaginations I 8).The chapters of In the American Grain seem to take out the stained glass windows from the cathedral of American history, taking them to the ground and offering new perspectives on this history. The text favors fragmentation over totality, bringing forth several different perspectives. For Williams, "Facts remain, but what is the truth?" (189). The truth is to be captured when one grasps the full dimension of historical figures, not simply by looking at the actions that turned them into heroes, or by looking at them as a portrait, which would not allow to contemplate them from different angles, but by looking at them as a sculpture. Williams fantasizes that Brancusi, whose studio he visited in Paris, should make a statue of Lincoln, suggesting how modernist sculpture informed his attempt at capturing the "spirit" of these historical figures: "I seek the support of history but I wish to understand it aright, to make it SHOW itself" (116). The object is to have history grow almost organically from the multiplicity of voices that constitute the text. Williams' historical reflection reads like a cubist portrait, capturing facts through glimpses, something which J. Hillis Miller explains very well: "Williams is the master of the glimpse. A line of his, suddenly leaping up out of the text, will throw the reader into an unexpected intimacy with his subject, like pushing open a door and advancing one's nose into some foreign face" (Hillis Miller 47).

Williams' modernist explorations with multiple voices and layers debunk traditional views in order to renew the national narrative and to reconcile the individual actions of historical figures and their meaning for the construction of the community. In that sense, Williams takes the project defined by Van Wyck Brooks to a new level. Brooks stated:

We must put aside anything that tends to make us self-conscious in this matter of American tradition and simply be American, teach our pulses to beat with American ideas and ideals, absorb American life, until we are able to see that in all its vulgarities and distractions and boastings there lie the elements of a gigantic art.

(The Wine of the Puritans 136)

Williams opens history to the "vulgarities and distractions" of American life by going against traditional visions of historical figures in order to "uneducate" readers and to make them rediscover the American experience. 
In this, implicitly, Williams puts himself in relation to another poet, Walt Whitman, who dedicated his Leaves of Grass to "A Historian." Like him, Williams seems to dedicate In the American Grain to all Americans, in order to turn them into historians thanks to their encounter with the local, to make them celebrate what Emerson called "this new yet unapproachable America" (Emerson 485). The American poetic tradition that correlates the lyrical to the historical finds in Williams one of its great practitioners: approaching the continent, allowing for a full encounter with the local is both Williams' concept of democratic action and of poetry.

In the American Grain owes much to a tradition that is deeply ingrained in American intellectual life: from Emerson's sense that history should be an incarnated biography to Whitman's celebration of the local to Brooks' calls for a new allencompassing perspective on American life. But Williams looked at these traditions, and particularly the grand American narrative of discovery, from a new array of perspectives: his textual experiments were a means to renewing the American democratic tradition, to offering a counter-narrative and trying to rescue American history from the Puritan tradition. Even though Williams only mentioned Whitman in passing, he did plan to distribute a tract based on Democratic Vistas during Al Smith's 1928 campaign: a gesture which signals his belief in the power of poetry to advance the course of history and which continued the gesture of In the American Grain.

His escape from a master narrative to a multiplicity of narratives opens the way to the rise of cultural criticism in the twentieth century, fusing together literary creation, linguistics, philosophy and history. In In the American Grain, Williams the "unprofessional historian," defined a new mode of writing that looked at history from a variety of perspectives in order to rediscover the local. Paving the way for the poetgeographer Charles Olson or the artist-geographer Robert Smithson, In the American Grain put forward the poetic dimension of space and time and brought together different types of discourses in order to try to "enter the world naked" and to try to awaken to it, as he suggested in Spring and All:

They enter the new world naked,

cold, uncertain of all

save that they enter. All about them

the cold, familiar wind-

Now the grass, tomorrow

the stiff curl of wildcarrot leaf

One by one objects are defined-

It quickens: clarity, outline of leaf

But now the stark dignity of

entrance-Still, the profound change

has come upon them: rooted, they

grip down and begin to awaken (I 96)

i. This gesture anticipates what Benedict Anderson will do decades later by describing Franklin and Jefferson as "Creoles". ("Frameworks of Comparison" 17) 


\section{BIBLIOGRAPHY}

Abrahams, Edward. The Lyrical Left and the Origins of Cultural Radicalism in American. Charlottesville, VA: U of Virginia P, 1986. Print.

Anderson, Benedict. Imagined Communities: Reflections on the Origin and Spread of Nationalism. London: Verso, 1991. Print.

---. "Frameworks of Comparison", London Review of Books, Vol. 38, No.2 (2-21 January 2016): 15-18. Print

Anderson, Sherwood. Puzzled America. New York: Paul P. Appel, 1970. Print.

Beck, John. Writing the Radical Center: William Carlos Williams, John Dewey, and American Cultural Politics. New York: SUNY P, 2001. Print.

Blake, Casey. Beloved Community: The Cultural Criticism of Randolph Bourne, Van Wyck Brooks, Waldo Frank and Lewis Mumford. Chapel Hill, NC: U of North Carolina P, 1990. Print.

Bloch, Marc. Apologie pour l'histoire ou métier d'historien. Paris: Armand Colin, 1952. Print.

Boas, Franz. The Shaping of American Anthropology, 1883-1911: A Franz Boas Reader. Ed. George W. Stocking Jr. New York: Basic Books, 1974. Print

Bremen, Brian A. William Carlos Williams and the Diagnostics of Culture. Oxford: Oxford UP, 1993. Print.

Breslin, James E. B. William Carlos Williams, an American Artist. Oxford: Oxford UP, 1970. Print.

Brooker, Peter, and Andrew Thacke, eds. The Oxford Critical and Cultural History of Modernist Magazines: Volume II: North America 1894-1960. Oxford: Oxford UP, 2012. Print.

Brooks, Van Wyck. “On Creating a Usable Past.” The Dial LXIV.764 (April 11, 1918): 337-41. Print.

---. America's Coming-of-Age. New York: B. W. Huebsch, 1915. Print.

---. The Wine of the Puritans: A Study of Present-Day America. London: Sisley’s, 1908. Print.

Burke, Kenneth. "Review, New York Herald Tribune Books, March 1926." William Carlos Williams:

The Critical Heritage. Ed. C. Doyle. New York and London: Routledge, 1997. 86-88. Print.

Cantrell, Carol H. “'Sufficient Ground to Stand On': Pound, Williams and American History."

Essays for Richard Ellmann. Ed. Susan Dick, Declan Kiberd, Dougald McMillan, Joseph Ronsley.

Montreal: McGill-Queen's UP, 1982. Print.

Carlyle, Thomas. On Heroes, Hero-Worship, and the Heroic in History. 1841. Fairford: Echo Library, 2007. Print.

Clifford, James. The Predicament of Culture: Twentieth Century Ethnography, Literature and Art. Cambridge, MA: Harvard UP, 1988. Print.

Coles, Robert. William Carlos Williams: The Knack of Survival in America. New Brunswick, NJ: Rutgers UP, 1975. Print.

Conn, Peter. The Divided Mind: Ideology and Imagination in America, 1898-1917. Cambridge: Cambridge UP, 1989. Print.

Conrad, Bryce. Refiguring America: A Study of William Carlos Williams' In the American Grain. Champaign, IL: U of Illinois P, 1990. Print. 
Davie, Donald. The Legacy of Fenimore Cooper. Oxford: Blackwell, 1959. Print.

Derrida, Jacques. Poétique et politique du témoignage. Paris: L'Herne, 2005. Print.

Dewey, John. “Americanism and Localism.” The Dial c. 1 vol. 68 (Jan-Jun 1920): 684-688. Print.

Dos Passos, John. Manhattan Transfer. 1925. Wilmington, MA: Mariner, 2003. Print.

Douglas, Ann. Terrible Honesty: Mongrel Manhattan in the 1920s. New York: Farrar, Strauss and Giroux, 1996. Print.

Doyle, Charles. William Carlos Williams: The Critical Heritage. New York and London: Routledge, 1997. Print.

Du Bois, W. E. B. Souls of Black Folk. 1903. Mineola, NY: Dover, 1994. Print.

East, James H. The Humane Particulars: The Collected Letters of William Carlos Williams and Kenneth Burke. Columbia, SC: U of South Carolina P, 2003. Print.

Eliot, T. S. The Sacred Wood: Essays on Poetry and Criticism. London: Methuen, 1920. Print.

Ellison, Ralph. "What America Would Be Like Without Blacks.” Collected Essays. Ed. John Callahan. New York: Modern Library, 2003. Print.

Emerson, Ralph. Essays and Lectures. New York: Library of America, 1983. Print.

Grieve-Carlson, Gary. Poems Containing History: Twentieth-Century American Poetry's Engagement with the Past. Plymouth: Lexington Books, 2014. Print.

Hegeman, Susan. Patterns for America: Modernism and the Concept of Culture. Princeton, NJ:

Princeton UP, 1999. Print.

Holder, Alan. "In the American Grain: William Carlos Williams on the American Past," American Quarterly 19.3 (1967): 499-515. Print.

James, William. The Principles of Psychology: Volume One, New York: Henry Holt and Company, 1890. Print.

Hillis Miller, Joseph. William Carlos Williams: A Collection of Critical Essays. Englewood Cliffs, NJ: Prentice-Hall, 1966. Print.

Hoopes, James. Van Wyck Brooks: In Search of American Culture. Boston: University of Massachusetts P., 1977. Print.

Kenner, Hugh. A Homemade World: the American Modernist Writers. New York: Knopf, 1975. Print.

---. The Pound Era. Oakland, CA: U of California P, 1973. Print.

Lawrence, D. H. Studies in Classic American Literature. 1923. Cambridge: Cambridge UP, 2003. Print. ---. “Review, Nation, 1926.” William Carlos Williams: The Critical Heritage. Ed. Charles Doyle. New York and London: Routledge, 1997. 89-92. Print.

Magee, Michael. Emancipating Pragmatism: Emerson, Jazz and Experimental Writing. Tuscaloosa, AL: U of Alabama P, 2004. Print.

Mariani, Paul L. William Carlos Williams: A New World Naked. New York: Norton, 1990. Print.

Marsh, Alec. Money and Modernity: Pound, Williams, and the Spirit of Jefferson. Tuscaloosa, AL: U of Alabama P, 2011. Print.

Matthiessen, Francis Otto. The American Renaissance: Art and Expression in the Age of Emerson and Whitman. 1941. Oxford: Oxford UP, 1968. Print. 
Mencken, Henry Louis. A Mencken Chrestomathy. New York: Vintage, 1982. Print.

Mitchell, Charles E. Individualism and Its Discontents: Appropriations of Emerson, 1880-1950. Amherst, MA: U of Massachusetts P, 2011. Print.

Nietzsche, Friedrich. On the Advantages and Disadvantages of History for Life. Indianapolis: Hackett, 1980. Print.

Olson, Charles. Call me Ishmael. New York: Grove Press, 1958. Print.

Orr, Linda. "The Revenge of Literature: A History of History." New Literary History 18.1 (1986):

1-22. Print.

Perloff, Marjorie. “'Lines Converging and Crossing': The 'French' Phase of William Carlos Williams.” The Missouri Review 2.1 (1978): 89-123. Print.

Poirier, Richard. Poetry and Pragmatism. New York: Faber \& Faber, 1992. Print.

Pound, Ezra. Cantos. New York: New Directions, 1996. Print.

Rorty, Richard. Achieving our Country. Cambridge, MA: Harvard UP, 1999. Print.

Rourke, Constance. The Roots of American Culture and Other Essays. New York: Harcourt, Brace and Company, 1942. Print.

Santayana, George. The Genteel Tradition in American Philosophy and Character and Opinion in the United States. New Haven and London: Yale UP, 2009. Print.

Schuster, Joshua. "William Carlos Williams, Spring and All and the Anthropological Imaginary." Journal of Modern Literature 30.3 (2007): 116-132. Print.

Slate, Joseph Evans. "William Carlos Williams, Hart Crane and 'The Virtue of History." Texas Studies in Literature and Language 6.4 (1965): 486-511. Print.

Stein, Gertrude. Selected Writings. Ed. Carl Van Vechten. New York: Vintage, 1990. Print.

Stokes, Claudia. Writers in Retrospect: The Rise of American Literary History, 1875-1910. Chapel Hill, NC: U of North Carolina P, 2006. Print.

Strachey, Lytton. Eminent Victorians. 1918. Mineola, NY: Dover, 2006. Print.

Tashjian, Dickran. William Carlos Williams and the American Scene, 1920-1940. New York: The Whitney Museum of Art, 1979. Print.

Tapscott, Stephen. American Beauty: William Carlos Williams and the Modernist Whitman. New York: Columbia UP, 1994. Print.

Thoreau, Henry David. A Writer's Journal. Ed. Laurence Stapleton. Mineola, NY: Dover, 1960. Print. Von Halberg, Robert. Charles Olson: the Scholar's Art. Cambridge, MA: Harvard UP, 1978. Print. Weaver, Mike. William Carlos Williams: The American Background. Cambridge: Cambridge UP, 1977. Print.

White, Eric B. Transatlantic Avant-Gardes: Little Magazines and Localist Modernism. Edinburgh: Edinburgh UP, 2013. Print.

White, Hayden. Metahistory: The Historical Imagination in Nineteenth-Century Europe. Baltimore and London: Johns Hopkins UP, 1973. Print.

Whitman, Walt. Leaves of Grass and Other Writings. Ed. Michael Moon. New York and London: Norton, 2002. Print. 
Will, Barbara. “The Strange Politics of Gertrude.” Humanities 33.2 (2012). Web.

Williams, William Carlos. Imaginations: Kora in Hell / Spring and All / The Descent of Winter / The Great American Novel / A Novelette And Other Prose. New York: New Directions, 1970. Print.

---. In the American Grain. New York, NY: New Directions, 1925. Print.

---. Paterson. Harmondsworth: Penguin, 1983. Print.

---. The Autobiography of William Carlos Williams. New York, NY: New Directions, 1967. Print.

---. Voyage to Pagany. New York, NY: New Directions, 1970. Print.

Whitaker. Thomas R. William Carlos Williams. New York: Twayne Publishers, 1989. Print.

\section{NOTES}

ii. Following James Clifford's reading of "The Pure Products of America Go Crazy" as an example of "ethnographic modernity," Joshua Schuster opposes the "Frazer/Eliot line of anthropological modernism based on myth and religious ritual" and argues "for the importance of the American anthropologist Franz Boas for reading Williams' Spring and All" (3). Schuster suggests that Williams must have been familiar with Boas' work. Boas was a close friend of Dewey's, whom Williams admired, and was also widely read among the poets (Schuster 6). Schuster quotes Boas suggesting that these words could have been a preface to Spring and All:

Thus we are concerned with the effects of the climate and the products of a country upon human life.... No less interesting to us are the phenomena of dependence of human life upon those social conditions that find expression in the customary mode of nutrition and occupation; in the effects of contact between neighboring groups of people; in modifications brought out by migrations; and in the forms of life as influenced by the density of the population. (6)

Boas' site-specific observations, his close study of the local, is indeed very evocative of Williams' focus on the primitive and the local.

iii. In his seminal book-length study of the book, Bryce Conrad underlines how In the American Grain was received as a poetic text and how the Horace Gregory introduction that has accompanied it since 1939 has situated it as a literary text rather than as a historical text. Conrad discards readings of the book as an accompaniment to Williams' poetry while acknowledging the work of Holder and Breslin, who looked at the book from the perspective of what it brings to historiography. Conrad defines the book as a literary and historical creation in its own right. However, as he explains, his project was not to look at the work from the perspective of its relation to contemporary historiography or to its modernist position. An analysis of these aspects of the work is however essential in order to show Williams' place on the spectrum of the history of ideas in twentieth-century America.

iv. Williams' biographer Paul J. Mariani describes Williams' bitter disappointment in the book's failure to find readers despite its positive reviews, among which those of the New York Times and the New York Tribune, and it should be noted that it was being taught at Harvard in the 1930s by Charles Olson.

v. "I never heard of Mencken as an influence in American letters save as one who came from behind to inform us that we have a language" (Mariani 243). But it should also be noted that some of Williams' comments in In the American Grain are very evocative of Mencken's scathing tone, such as for example the following description of Benjamin Franklin: "He is our wise prophet of chicanery, the great buffoon, the face on the penny stamp" (In the American Grain 156). 
vi. Williams' project echoes from afar Nietzsche's call for a separation from monumental and antiquarian history in order to focus on a critical history, one that would be "useful" to the historian and his readers by allowing them to rediscover their present conditions.

vii. The philosopher Richard Rorty in Achieving our Country has pointed out how deeply ingrained in American culture is the notion that the country is not yet "achieved," and that it remains in the process of being discovered and imagined, something which is at the basis of the book.

viii. In this respect, Williams is very close to William James who analyzed Grote and Russel's opposition between "knowledge by acquaintance" and "knowledge by description." Williams' project is indeed to acquaint his readers with history directly and unmediated, to make history "show itself" (In the American Grain 87).

\section{ABSTRACTS}

Through a reading of William Carlos Williams' In the American Grain (1925), this paper seeks to look at the questions raised by the writing of history in the modernist context and to explore Williams' particular definition of history.Williams' historical project turns history into a literary question through a text that is a collage of very different voices, narratives, and shifts of perspective, thus raising the question of how to write history. Williams' foreword suggests the impossibility of writing a true history and points rather to the desire to capture an evanescent reality, what he calls "the phosphorus of the life". Williams attempts to write the history of a "homemade world" to use Hugh Kenner's eloquent phrase; rather than looking at Europe as his friend Pound was doing at the time, the text presents variations on recurring motifs of American history, problematizing the notion of a "new" continent and of the discovery of place. Williams' poetic repossession of history calls for a reflection on the type of history he sought to write. In the American Grain looks at the "beginners" that have made American history, from the Spanish explorers to Poe, and questions the naïve notion of "beginning". William Carlos Williams' In the American Grain is a biography of the American cultural imagination that puts in dialogue the national epic with a perspectival counter history.

\section{INDEX}

Keywords: anthropology, beginnings, cultural criticism, D. H. Lawrence, discovery, Ezra Pound, Franz Boas, history, Hugh Kenner, John Dewey, Kenneth Burke, Marcel Duchamp, modernism, poetry, Ralph Waldo Emerson, T. S. Eliot, the canon, the local, Van Wyck Brooks

\section{AUTHOR}

\section{ANTONIA RIGAUD}

Université Sorbonne Nouvelle 